\title{
ARAŞTIRMA MAKALESI/RESEARCH ARTICLE \\ FROM SUAKIN ISLAND TO COMOROS ISLANDS: EAST AFRICAN MUSLIMS' STRUGGLE FOR EXISTENCE
}

\author{
Kadir ÖZKÖSE \\ Prof Dr. Cumhuriyet Üniversitesi, İlahiyat Fakültesi, Tasavvuf, Sivas \\ Prof. Dr. Cumhuriyet University, Theology Faculty, Sufism, Sivas/Turkey \\ kadirozkose60@hotmail.com \\ orcid.org/0000-0003-3977-3863 \\ https://ror.org/04f81fm77
}

\begin{abstract}
Suakin Island is a strategically important island in the northeast of the Sudanese Republic and on the Red Sea coast. The Comoros Islands, on the other hand, are islands located in the south east of Africa, in the west of the Indian Ocean. East Africa coasts extending from the Red Sea coast in the north of Africa, to the Comoros Islands located in the south of Africa are very special and fertile lands that have hosted the culture and civilization of Muslim peoples. These lands, which are the subject of this article, have a difficult nature in terms of both geographical and climatic conditions, have been exposed to the invasion and influx of powerful states throughout history. Especially the dreams of Portuguese sailors who wandered around the Cape of Good Hope to transfer the riches of the east to the west caused the western powers to turn their attention to this geography in the sixteenth century. In our article, we draw attention to the formation of the Islamic civilization of the coasts of East Africa and the Red Sea and the development phase of this cultural texture called the Swahili civilization. We tried to focus on the Harar sultanates and the Abyssinian State of the Ottoman Empire. It is preferred to give point to the strategic location of the cities of Suakin, Masawa and Zeila, which are the administrative centers of the Abyssinian state. We see that the Ottoman navy, which dominated the Red Sea for three centuries and prevented the Portuguese invasion, organized voyages in the Indian Ocean in the direction of Yemen, Basra and the Indian through the Bosporus of Bâbü'l-Mendeb, as well as voyages along the coast of East Africa to the lands of today's Somalia, Kenya and Tanzania. In our article, it will be clarified that how East African Muslims had a bond of affection with the Ottoman Empire until the First World War.
\end{abstract}

Key Words: The Ottoman State, East Africa, Swahili Civilization, Suakin Island

\section{SEVÂKIN ADASINDAN KOMOR ADALARINA DOĞU AFRIKA MÜSLÜMANLARININ VAROLUŞ MÜCADELESI}

Öz

Sevâkin Adası günümüz Sudan Cumhuriyeti'nin kuzeydoğusunda ve Kızıldeniz kıyısındaki stratejik öneme sahip bir adadır. Komor Adaları ise Afrika'nın güney doğusunda Hint Okyanusu'nun batısında yer almaktadır. Afrika'nın kuzeyinde Kızıldeniz sahili'nden Afrika'nın güneyinde yer alan Komor Adalarına kadar uzanan Doğu Afrika sahilleri Müslüman halkların kültür ve medeniyetine ev sahipliği yapmış çok özel ve bereketli topraklardır. Makalemizde gerek coğrafi gerekse iklim koşulları bakımından zorlu bir hüviyete sahip olan bu topraklar tarih boyunca güçlü devletlerin istila ve akınına maruz kalmıştır. Özellikle Ümit Burnu'nu dolaşan Portekiz denizcilerinin şarkın zenginliklerini batıya aktarma hülyaları XVI. yüzyılda batılı güçlerin dikkatlerini 
bu coğrafyaya çevirmesine yol açmıştır. Makalemizde Doğu Afrika ve Kızıldeniz sahillerinde İslam medeniyetinin teşekkülü ve Sevahil medeniyeti adı verilen bu kültürel dokunun gelişim evresine dikkat çekmekteyiz. Harar sultanlıkları ve Osmanlı Devleti'nin Habeş Eyaleti üzerinde durmaya çalışılmıştır, Habeş eyaletinin yönetim merkezi konumundaki Sevâkin, Masavva ve Zeyla kentlerinin stratejik konumundan bahsedilmiştir. Osmanlı donanmasını, üç asır boyunca Kızıldeniz'de hakimiyet kuran ve Portekiz işgaline engel olduğunu, Bâbü'l-Mendeb Boğazından geçerek Hint Okyanusunda Yemen, Basra ve Hint istikametinde yöneldiklerini, Doğu Afrika sahilleri boyunca günümüz Somali, Kenya ve Tanzanya topraklarına kadar seferler düzenlediklerini görmekteyiz. Makalemizde Doğu Afrika Müslümanlarının Osmanlı Devleti ile gönül bağının I. Dünya Savaşına kadar devam ettiği konusuna açıklık kazandırmaktadır.

Anahtar Kelimeler: Osmanlı Devleti, Doğu Afrika, Sevahil Medeniyeti, Sevâkin Adası

Atıf / Cite as: Özköse, Kadir. "From Suakin Island to Comoros Islands: East African Muslims' Struggle for Existence” Apjir 5/2 (Ağustos 2021), 167-187.

\section{Introduction}

The region stretching from Zambezi to the Gulf of Aden and then to the lands of Sudan and Red Sea coast of Egypt is roughly called East Africa. During the colonial period, the region was divided into two protectorates as British and German parts. Among the East African Community (EAC) member countries Tanzania, Kenya, Uganda, Rwanda and Burundi are also located in the Great Lakes Region. Burundi and Rwanda are considered as part of Central Africa as well as East Africa. Djibouti, Eritrea, Ethiopia and Somalia are located in the region known as the Horn of Africa. The Comoros, Mauritius and Seychelles are small island countries in the Indian Ocean whereas Reunion and Mayotte are overseas territories in the Indian Ocean. Mozambique and Madagascar, on the other hand, are considered a part of South Africa. Malawi, Zambia and Zimbabwe, which are generally located in South Africa and formerly included in the Central African Federation, are located in both Central Africa and East Africa. ${ }^{1}$

According to the classification made by African Development Bank, East African countries consist of Djibouti, Eritrea, Kenya, Somalia, Sudan, Tanzania, Comoros, Seychelles Burundi, Ethiopia, South Sudan, Rwanda and Uganda. ${ }^{2}$ Among the East African countries, Djibouti, Eritrea, Kenya, Somalia, Sudan and Tanzania are the countries that have coastlines on the Indian Ocean or the Red Sea. Comoros and Seychelles are the island countries of East Africa. While East African countries constitute $26 \%$ of the total population of the African continent with a population of 264 million, it constitutes only $16 \%$ of the continental economy. ${ }^{3}$

East African peoples consist of the Sudanese, Nilots, Dinkas and Masais. People in Sudan and the Lower Nile regions resemble to those in West African blacks. Black people living

\footnotetext{
${ }^{1}$ Ramazan Özey, “Doğu Afrika Panoraması: Siyaset-Toplum-Ekonomi”, Dünya Siyasetinde Afrika 3, ed. İsmail Ermağan, Nobel Yayınları, Ankara 2016, s. 1.

${ }^{2}$ Bahtiyar Dursun, "Doğu Afrika'da Yenilebilir Enerji Kaynakları: Potansiyel ve Yatırımlar”, Dünya Siyasetinde Afrika 3, ed. İsmail Ermağan, Nobel Yayınları, Ankara 2016, s. 374-375.

${ }^{3}$ Oktay Salih Akbay, "Doğu Afrika Ekonomileri", Dünya Siyasetinde Afrika 2, ed. İsmail Ermağan, Nobel Akademik Yayıncllı, Ankara 2015, s. 324.
} 
around the Nile are also called Nilotik. Another branch of the blacks who mix with the white race along the Nile are Fellahs, who form a part of the Egyptian people. Masai, Nandi and Suk tribes from the blacks living in Northeast Africa and Kenya also have the characteristics of the Hami race. ${ }^{4}$

The Red Sea, which is an important trade route around the world and has a transition between continents, has geopolitical importance in every period of history. ${ }^{5}$ Aden, Jeddah, Jar (Büreyke), Qulzum, Eyle (Aqaba), Yenbu, Aydhab, Shuaiba, Zebīd (Galafîka), Suakin, Quseir, Muha, Zeila, Bādi ', Dehlek, Beylul, Berbera, Mogadishu, Merka, Brava, Mombasa and Zanzibar have been the port cities of the Red Sea with high levels of commercial activity throuhout the history. ${ }^{6}$ Suakin, Masavwa, Beylul, Obuk, Tacura, Zeila and Berbera are the Red Sea ports that are the vital points of East African trade and transportation. Masavwa holds a special place for the Sudanese and Abyssinians. ${ }^{7}$

With its natural landscapes, climate and physical beauties, East Africa has always been an attractive settlement area. Snow-capped mountains such as Klimanjaro and Mount Stanley, hot and damp coastal plains are among the geographical beauties of East Africa. Klimanjaro Mountain, which belongs to Tanzania, was declared a World Natural Heritage by UNESCO in 1987. Due to its special location, countries such as Germany, Belgium, France and England are still unable to withdraw from their colonies in East Africa today. East Africa, being an agricultural center of coffee, tea, cotton and oilseeds production, led to the permanent settlement of the colonial powers in the region. ${ }^{8}$

\section{Introduction of Islam Into East Africa}

The first state established in Africa is the Kingdom of Axum, which had dominated the Eastern Africa. The Kingdom of Axum was established in a hinterland covering the present-day Ethiopia, Somalia, Eritrea and Djibouti. Like Egypt, East Africa is considered to be one of the ancient lands in human history. It is known that Axumians sailed in the eighth century BC., established relations with India and Ceylon, they dominated Egypt during the time of Axum King Shabaka (712-663 BC), and adopted Christianity in the fourth century AC. Capturing the vast coastal regions stretching from the Nile Valley to the Red Sea, Sudan and Somalia, the Kingdom of Axum had become the dominant power

\footnotetext{
${ }^{4}$ Ramazan Özey, “Doğu Afrika Panoramasi: Siyaset-Toplum-Ekonomi”, Dünya Siyasetinde Afrika 3, ed. İsmail Ermağan, Nobel Yayınları, Ankara 2016, s. 2.

${ }^{5}$ Hakan Aydın, "Eleştirel Jeopolitik Perspektifi İle Kızıldeniz", Dünya Siyasetinde Afrika 3, ed. İsmail Ermağan, Nobel Yayınları, Ankara 2016, s. 258.

${ }^{6}$ Nihal Şahin Utku, Kızıldeniz'de Denizcilik, Ticaret ve Yerleşim (VII-XI. Yüzyllar), Doktora Tezi, Marmara Üniversitesi Sosyal Bilimler Enstitüsü, İstanbul 2005, s. 477-628; Cengiz Orhonlu, Osmanlı İmparatorluğunun Güney Siyaseti Habeş Eyaleti, Türk Tarih Kurumu Basımevi, Ankara 1996, s. 175; Muhammed Tandoğan, Afrika'da Sömürgecilik ve Osmanll Siyaseti (1800-1922), Türk Tarih Kurumu Yayınları, Ankara 2013, s. 141-142.

${ }^{7}$ Durmuş Akalın \& Selim Parlaz, XIX. Yüzyılda Doğu Afrika'da Osmanllar ve İtalyanlar, Kesit Yayınları, İstanbul 2015, s. 295.

${ }^{8}$ Cihan Daban, "Bağımsızlıktan Günümüze Uganda Cumhuriyeti ve Dış İlişkileri”, Dünya Siyasetinde Afrika 5, ed. İsmail Ermağan, Nobel Yayınları, Ankara 2018, s. 123.
} 
in the region. The Kingdom of Axum, which became effective in the East, Central and North Africa, developed its relations with the Byzantine Empire and with the Muslim peoples over time. The success of the conquest movements and the strengthening of the Muslims in North Africa damaged the relations of the Kingdom of Axum with the Byzantine Empire. The seizure of the ports and trade routes, which are the important sources of income for the Kingdom of Axum, by the Muslims led eventually to the collapse of the Kingdom of Axum . ${ }^{9}$

In the early periods of the Islamic history, the Kharijites took refuge in North Africa and the Zaydis migrated to the coasts of Somalia and East Africa as a result of being disturbed by the Umayyad rule. The group that migrated to Africa during the reign of Abbasids became the Umayyad authorities this time. While some of them moved from North Africa to the Iberian peninsula and pioneered the establishment of the Andalusian Umayyad State, certain Umayyad officers settled on the coast of East Africa. The presence of Muslims on the East African coast was increasing day by day with mass migrations for political, social, religious and commercial purposes. During the reigns of the Abbasid caliphs Hārūn Ar- Rašīd and al- Al-Ma’mūn, the commercial expeditions were organized to the western coasts of the Indian Ocean, and the taxation system was introduced. Under the rule of the Abbasid Palace, Muslim merchants organized expeditions from the Persian Gulf to the East African islands. Oman, Yemen, Arab, Iranian and Turkish merchants organized regular commercial voyages on the Indian Ocean from India to Indonesia, from the Persian Gulf to the Red Sea, from the north to the south of Africa and to all East African coasts. During the Abbasid rule, another mass migration wave was experienced due to the conflicts between the sect and the fights for the throne that arose in and around the Persian city of Shiraz. Over time, nearly forty independent sultanates began to be established on the coastline extending from today's Somalia to the south of Mozambique. Although most of these dynasties are in the position of site state or island sultanate, some states such as the Kilve Sultanate have hosted many dynasties. ${ }^{10}$

The most important of these dynasties was the Harar Emirate. Merchants and emirs coming from Yemen became dominant in the Harar region. The Muslims established the Awfat Dynasty, which ruled between 1285 and 1415. The Awfat Dynasty was able to fight the Kingdom of Abyssinia, which was the center of Christianity, and change the balance of power. Meanwhile, the Emirate of Adel was established to replace the Awfat Dynasty, which weakened upon the Abyssinian attack. The Emirate of Adel was also called the

\footnotetext{
${ }^{9}$ Hıfzı Topuz, Kara Afrika: Bir Kıtanın Dünü Bugünü ve Yarını, Milliyet Yayınları, İstanbul 1971, s.19-23; Abebaw Fentahun Gezahegn, Tarihte Jimma Şehri, Yayınlanmamış Yüksek Lisans Tezi, Gazi Üniversitesi Sosyal Bilimler Enstitüsü, Ankara 2016, s. 7-15; Cihan Daban, "Etiyopya-Somali İlişkileri: Ogaden Savaşı”, Dünya Tarihinde Afrika 4, ed. İsmail Ermağan, Nobel Akademik Yayıncılık, Ankara 2017, s. 255-256.

${ }^{10}$ Ahmet Kavas, Geçmişten Günümüze Afrika, Kitabevi, 2. Baskı, İstanbul 2017, s. 58, 120-121
} 
Emirate of Zeila, which, was actually administered from Zeila at the confluence of the Red Sea and the Indian Ocean. ${ }^{11}$

As a result of the religious, political, commercial and social expeditions, a distinctive civilization of the Islamic World emerged in East Africa. This civilization was named "Kiswahili Civilization" meaning coast and/or coastal civilization. The capital of Somalia, Makdishu as well as Kenya's Mombasa, Tanzania's Kilve and Mozambique's Sofala are the most popular points of this civilization. Lamu in Kenya, Tanzania, Zengibar, Comoros Islands and Madagascar constitute the extension of the Swahili civilization. ${ }^{12}$

The famous traveler Ibn Battuta had traveled to East African cities from Makdishu to Kilve in 1331. He states that the people of Kilve lived in multi-storey wooden buildings, and that the sultan of Kilve was generous enough to sacrifice everything for his people. He also adds that Kilve used to be one of the most beautiful cities in the Islamic world. While it is mentioned in Islamic sources that the region is referred to as "Bilād al-Zunūj" meaning the "country of Zanj, i.e. Black people" and that there is a kingdom consisting of black people in the region, Ibn Battuta mentions the region as "Bilād al-Swahili (Kiswahili)" for the first time ${ }^{13}$. In time, the generation born from the marriage of Muslims from the Arabian Peninsula and Shiraz with women from the native Bantu tribe was called "Swahili (Kiswahili)". Today, Swahili language is a common language spoken from Somalia to the eastern part of the Democratic Republic of Congo. The Swahili language is a mixture of Arabic and Persian and Bantu languages. ${ }^{14}$

\section{The Exposion of East African Coast to Portuguese Occupation}

With the fall of Andalusia, the Spanish and Portuguese powers wanted to keep their pace and continue their progress. As the Spanish sailors were planning to dominate the Mediterranean coast with their sea voyages to North African lands, they confronted Ottoman navy; on the other hand, the advance of the Spanish powers came to an end and the Mediterranean was turned into a Turkish sea along with the long struggle of the Ottomans. During the fall of Andalusia, Portuguese naval forces, like the Spanish powers, sailed to the oceans and organized voyages on the west coast of Africa. Portuguese navies, which formed their own colonies in West Africa, started to move eastward through the Cape of Good Hope. ${ }^{15}$ The fact that Vasco da Gama toured the Cape of Good Hope in South Africa in 1497 and went to India through the East African coast changed the history of the peoples of East Africa in a negative manner. While this expedition was considered a great success in European history, it marks the beginning of a painful future for the Islamic World. Although Vasco da Gama traveled the islands of the Indian Ocean with all kinds of

\footnotetext{
${ }^{11}$ Ahmet Kavas, Osmanlı-Afrika İlişkileri, TASAM Yayınları, İstanbul 2006, s. 111.

${ }^{12}$ Ahmet Kavas, Geçmişten Günümüze Afrika, Kitabevi, İstanbul 2005, s. 81-82.

${ }^{13}$ Ebû Abdullah Muhammed İbn Battûta Tancî, İbn Battûta Seyahatnâmesi, çev. A. Sait Aykut, Yapı Kredi Yayınları

2. Bask1, İstanbul 2004, c. 1, s. 361-369

${ }^{14}$ Kavas, Geçmişten Günümüze Afrika, s. 59.

${ }^{15}$ Kavas, Geçmişten Günümüze Afrika, s. 121.
} 
support and guidance of Muslims, he pioneered the invasion plans for Muslims. A few years after this expedition, the Portuguese navy sailed into the Indian Ocean in 1500, using the same route. Portuguese seafarers taxed each of the vulnerable island cities they visited. When the Portuguese powers thought that they would continue their advance easily in this way, the peoples of the region realized that the Portuguese sailors did not sail to the Indian Ocean and the Red Sea with an innocent course and that they came with imperialist ambitions. As a matter of fact, they confronted the Portuguese powers, defended their lands and protected their sovereignty. Realizing that the local powers were taking a reactive attitude, Portuguese forces began to appear on the East African coast in 1505 with a larger navy. The advances of the Portuguese forces intended to demolish the region, and they tried to overcome even the smallest rebellious groups confronting the occupation army by burning them down. ${ }^{16}$ In the meantime, the Portuguese army employed the indigenous peoples against the Muslims who created obstacles for their occupation plans and showed resistance against their occupation. They took the advantage of the Zimba tribe, one of the most brutal African tribes living in Mozambique, for their own occupation ambitions. They took them from Mozambique to the East African coast. In their advance towards the north, the Portuguese destroyed the cities by artillery fire by the sea as the native and wild Zimba peoples attacked the Muslims by land. The Portuguese navy entering the Red Sea came before Jeddah. Their ultimate aim was to destroy the holy lands of Islam. Sultanates in East Africa had been abolished. Tens of thousands of Muslims were killed. Only the ruins have survived from the coastal civilizations that have been unearthed for seven centuries. ${ }^{17}$

\section{The Ottoman Navy in The Aid Of The East African Peoples}

When the Ottomans stopped the advances of the Portuguese on the north of East Africa and the Red Sea coast with their sea expeditions, the Sultanate of Oman came to the rescue of the Muslims living on the East African coast in the Indian Ocean. The Islamic civilization continued its existence in the region with the help and support of the Ottoman and Oman Sultanate in any case. Thus they paved the way for the spread of Islam in Kenya, Tanzania, Rwanda, Congo, Malawi, Mozambique and Madagascar. ${ }^{18} \mathrm{Facing}$ the advancement and destruction of Portuguese forces in the Indian Ocean, the ruler of Gujarat, Mahmud Khan, appealed to the Mamluk Sultan Qānșūh al-Ghawrī and asked him to help them against the Portuguese. However, the fleet sent by the Mamluk Sultan alGhawrī was unsuccessful and ineffective. After the Mamluks withdrew from the stage of history, the Indian Muslims sought help from the Ottoman Empire immediately.

When Yavuz Sultan Selim conquered Iraq and dominated the Persian Gulf, the Ottoman State responded to the aid request from India, formed the Suez fleet, and the Ottoman fleet under the command of the Egyptian Governor Hadım Süleyman Pasha captured

\footnotetext{
${ }^{16}$ Kavas, Geçmişten Günümüze Afrika, s. 60.

${ }^{17}$ Kavas, Geçmişten Günümüze Afrika, s. 121.

${ }^{18}$ Kavas, Geçmişten Günümüze Afrika, s. 122.
} 
Aden, the gate of the Red Sea. The conquest of Eden made a great contribution for maintaining the security of Egypt, Hijaz, Yemen and Abyssinia. Afterwards, a series of naval battles took place between the Ottoman fleets under the command of Pīrī Reis, Murad Reis and Seydi Ali Reis, and the Portuguese. However, the Ottoman State could not prevent Portugal and then Holland from entering Asia. During the reign of Suleiman the Magnificent, the Ottoman forces under the command of Özdemir Pasha and his son Özdemiroğlu Osman Pasha annexed Eritrea, Djibouti, Somalia, the coasts of Sudan as well as a part of Abyssinia to the Ottoman lands in East Africa. ${ }^{19}$

\section{Sea Expeditions of Özdemir Pasha}

That Özdemir Pasha annexed Suakin and Masawa to the Ottoman Empire was a turning point. Özdemir Bey, who was acquainted with the region, defeated the Christian Kingdom of Dongola as a result of the campaigns he started and captured the east of Sudan as well as the northern parts of Ethiopia. In his campaigns, he enabled a large number of Muslim Arab tribes to settle in Sudan. Özdemir Pasha tried to win the hearts of the indigenous peoples by meeting their basic needs and rights instead of the policy of exterminating the Christians of the region. It is possible to say he prepared an environment of peace, not a conflict society. The mosque he built in Debarva and the masjids he built in the region served as the centers for the spread of Islam. As a result of Özdemir Bey's efforts, Sudan, which was affiliated to the General Governorship (Beylerbeylik) of Egypt, was attached to the Abyssinian Governor General in 1555. Özdemir Pasha paved the way for the establishment of the Ottoman administration with the support of local tribes. ${ }^{20}$

Özdemir Bey established a garrison in Aswan and made it possible to advance in the direction of Ibrim and Say. Özdemir Pasha, who was also the governor of Yemen, played a great role in the spread of Ottoman domination to certain parts of Africa. In the regions where the Berbers and Abyssinians lived, the Ottoman presence on the Red Sea coast was strengthened, and the Suakin and Masawa came under Ottoman rule. After the state of Abyssinia was established, Ottoman trade centers began to be formed on the Red Sea coast. In 1557, Masawa and the surrounding lands were captured. Arkiko, an important center of the Abyssinian Kingdom, was conquered. Islands like Dahlak across the Masawa, which is under the administration of Yemen, were annexed to the Abyssinian State. As a result of Özdemir Pasha's efforts, the Ethiopian State became a state in the south of Sudan, including Eritrea, Ethiopia, Djibouti and Somalia, dominating strategic points such as Suakin and Masawa. ${ }^{21}$

\footnotetext{
19 İ. Hakkı Uzunçarşıll, Osmanlı Tarihi, Türk Tarih Kurumu Basımevi, Ankara 1995, c. 2, s. 391-400; Y. Hikmet Bayur, Hindistan Tarihi, Türk Tarih Kurumu Basımevi, Ankara 1987, c. 2, s. 33; Numman Hazar, Küreselleşme Sürecinde Afrika ve Türkiye-Afrika İlişkileri, Usak Yayınları, 2. Baskı, Ankara 2011, s. 117.

${ }^{20}$ Mehmet Koçak, Mehdi Hareketinden İslâm Devrimine Sudan, Esra Yayınları, Konya 1999, s. 16-17; Muhammed Tandoğan, Afrika'da Sömürgecilikve Osmanlı Siyaseti (1800-1922), Türk Tarih Kurumu Yayınları, Ankara 2013, s. 143.

${ }^{21}$ Salih Özbaran, Umman'da Kapışan İmparatorluklar Osmanlı ve Portekiz, Tarihçi Kitabevi, İstanbul 2013, s. 156-157; Akalın \& Parlaz, Doğu Afrika'da Osmanllar ve Italyanlar, s. 14-15.
} 


\section{Ottoman Sea Expeditions from Suakin to Mombasa}

Hasan Pasha, who was appointed by Sultan Murad III as the Governor of Yemen, successfully undertook the administration on behalf of the Ottoman Empire in Yemen, the Red Sea, the Gulf of Aden, Oman, the Persian Gulf and the East African coast between 1580-1604, and he contributed to the region's being connected to the central province as well. ${ }^{22}$

Emir Ali Bey, appointed by Yemen Governor Hasan Pasha in 1580, became a beacon of hope for Muslims living in the islands of the Indian Ocean and the Red Sea coast. Following the expeditions of Salih Pasha in the Great Sahara and those of Özdemir Pasha and his son Osman Pasha in Sudan and Somalia, Ali Bey toured the East African coast.

Ali Bey gained a reputation by seizing Oman's Muscat Port. Ali Bey reached the Indian Ocean from the Port of Aden in 1584, sailed south, crossed the Somali coasts entirely, crossed the equator line to the south, and anchored at Malindi Port, which is located 100 $\mathrm{km}$ away from south of Mombasa. Possessing a considerable power, Ali Bey returned to Aden, and the officers he left in Kenya sustained the Turkish administration. Upon the success of the 1584 expedition, Yemen Governor Hasan Pasha sent Ali Bey back to East Africa. Ali Bey came to Kenya with four galleys with a number of small war and transport ships. On March 5, 1589, when Ali Bey was in Mombasa, the Portuguese navy entered Mombasa. The Turkish fleet was raided and burned. ${ }^{23}$

There are different rumors about the fate of Emir Ali Bey in the sources. Some sources mention that he was martyred here whereas others claim that he was captured by the Portuguese and taken to Lisbon. And some sources state that he was converted to Christianity by being forcibly baptized in Lisbon, and some sources state that he died in captivity. ${ }^{24}$ The surviving Turkish marine corps went south to Tanganyika and were killed there by wild natives. Due to his bold attitude, sources referred to Ali Bey as "Adventurer Ali Bey" 25 . The local sultanates supported Emir Ali Bey, who sailed to the African coast from the Gulf of Aden, and some of the sultans accompanied his galley in small boats. Emir Ali Bey, who went as far as Makdishu, Malindi archipelago and Mombasa, managed to connect these cities to the Ottoman administration. ${ }^{26}$

The Ottoman rule over Mombasa twice aroused the Portuguese. The second Mombasa expedition of the Ottomans, which started well but ended in defeat, caused the Portuguese to massive in order not to dispose of Mombasa. They moved their naval contingent from Malindi to Mombasa in order to block the Ottomans. The castle named

\footnotetext{
${ }^{22}$ Kavas, Geçmişten Günümüze Afrika, s. 62.

${ }^{23}$ Y1lmaz Öztuna, “Orta ve Doğu Afrika'da Türkler”, Hayat Tarih Mecmuası, No. 7, Ağustos 1973, s. 8-12; Hazar, Küreselleşme Sürecinde Afrika, s. 118-119.

${ }^{24}$ Kavas, Geçmişten Günümüze Afrika, s. 63-64.

${ }^{25}$ Öztuna, "Orta ve Doğu Afrika'da Türkler”, Hayat Tarih Mecmuası, s. 8-12; Hazar, Küreselleşme Sürecinde Afrika, s. 118-119.

${ }^{26}$ Kavas, Geçmişten Günümüze Afrika, s. 62-63.
} 
Fort Jesus, built by the Portuguese in Mombasa between 1592-1596, is the first castle built by the Europeans on the East African coast. Not content with moving their troops to Mombasa, the Portuguese brought a Shiraaz family from Malindi where they worked in harmony, and enabled them to establish a dynasty affiliated to them in Mombasa. Another center built by the Portuguese in Mombasa in 1597 was the monastery dedicated to the missionaries. ${ }^{27}$

\section{Oman Administration in East Africa}

The people of Oman, who exhibited a fierce struggle against the Portuguese, not only took Muscat from the Portuguese in 1650, but also led the liberation of Mombasa from the Portuguese invasion with the delegations they sent to Mombasa. Imam of Oman Said b. Seyf assigned Shahdād $b$. Shahadi to organize the Mombasa Muslims against the Portuguese. Amīr Shahdād, who collaborated with the people of Mombasa and formed a resistance force from the locals, took it from the Portuguese in 1680 following a five-year struggle. ${ }^{28}$

After Amīr Shahdād, who ruled Mombasa on behalf of Oman, the Mombasa administration was executed run by the Mazrūi family. Taking advantage of family fights, the Portuguese seized Mombasa in 1728 with the advantage of the disagreements within the Mazrūi family. However, the people of the city did not want to hand over Mombasa easily to Portugal. So much so that Mombasa administration had been exchanged between Muslims and Portuguese nine times. Therefore, the Mazrūī Family ruled Mombosa on behalf of the imams of Oman for approximately 140 years until $1837 .{ }^{29} \mathrm{After}$ the Mazrūī family lost power in 1837, the administration of Mombasa was carried out by the Bū Saĩd dynasty in Zengibar until $1895 .{ }^{30}$ The Dynasty, which was getting closer to the Ottoman Empire day by day, left Oman in 1860 and became an independent sultanate after having established direct relations with the Ottoman Empire and strengthened its contact. ${ }^{31}$ With the collapse of the Bū Saìd Dynasty, Mombasa was occupied by the British in $1895 .{ }^{32}$ Sultan Burgas, the sultan of Zengibar, who had also close contact with Istanbul against the activities of the British, French and Germans, had developed mutual relations with Ottoman Sultan Abdulhamid II. Although Mombasa was occupied by England in 1895, Seyyid Ali b. Hamud came to Istanbul and was hosted in Istanbul as the guest of the Ottoman Sultan. Sultan Seyyid Ali, who later left for Europe, passed away while he was in

\footnotetext{
${ }^{27}$ Kavas, Geçmişten Günümüze Afrika, s. 64.

${ }^{28}$ Kavas, Geçmişten Günümüze Afrika, s. 65-66.

${ }^{29}$ Kavas, Geçmişten Günümüze Afrika, s. 66.

${ }^{30}$ Ahmet Kavas, “Tarihi Süreçte Sahra Altı Afrika: Osmanlı-Afrika İlişkileri ve Sömürgecilik”, Sahra Altı Afrika, trc. Begüm Eda Şahin, ed. Ahmet Kavas \& Ufuk Tepebaş, Tasam Yayınları, İstanbul 2007, s. 78.

${ }^{31}$ Ahmet Kavas, "Tarihi Süreçte Sahra Altı Afrika: Osmanlı-Afrika İlişkileri ve Sömürgecilik”, Sahra Altı Afrika, trc. Begüm Eda Şahin, ed. Ahmet Kavas \& Ufuk Tepebaş, Tasam Yayınları, İstanbul 2007, s. 78.

${ }^{32}$ Kavas, Geçmişten Günümüze Afrika, s. 67.
} 
Paris. He was buried in the part belonging to Muslims in Pére Lachaise Cemetery, which was allocated for the citizens of the Ottoman Empire in Paris. ${ }^{33}$

Thanks to the military support provided by Özdemir Pasha and his supporters, the Muslims in the Horn of Africa were saved from extinction in the sixteenth century. The Harar Sultanate, which ruled in the region with the support and assistance provided by the Ottomans, preserved its existence until the end of the nineteenth century. ${ }^{34}$ The coasts of Sudan in the Red Sea were united with the Ethiopian State, and the lands of Sudan became an Ottoman province only in $1821 .^{35}$

\section{Suakin Base}

Upon the conquest of Egypt by Yavuz Sultan Selim, the Ottoman Empire seized the domination areas of the Mamluks. He contacted the territories of Sudan and made Suakin island the center of the Abyssinian State as a sanjak. He, then, connected the north and east of Sudan to the Abyssinian State.

The main factor that drove the Ottoman Empire to be interested in strategic points such as Suakin and Masawa on the East African coast was the risk of Portuguese penetration and the danger of closing the Strait of Bāb al-Mandab. With the Portuguese closing the Bāb al-MandabStrait, they would prevent Muslim sailors from entering the Red Sea with their ships. ${ }^{36}$

Suakin island is a strategically important port city located in the middle of the Red Sea stretching from Yemen to Suez. Ships traveling between Suez and Yemen stopped by this port and continued their journey ${ }^{37}$ Suakin Island, located on the opposite side of Jeddah, was a frequent destination for pilgrims going to Hejāz. The food needs of the pilgrims were provided from Suakin Island. Suakin Island was the indispensable point of dominating the Red Sea. It had a geostrategic importance in terms of war strategy. The Ottoman Empire would ensure the safety of Hejāz from Suakin Island by a desire to ensure the security of the holy towns. Suakin Island, with its harbor and large agricultural lands, was also the sea transportation resort of Sudan. It was an area where hegemony as well as the military and commercial activity in the Red Sea were controlled. Suakin port was one of the distinguished and busy ports of the Red Sea. For the Ottoman Empire, this place was both a military base and a customs port. The defense of Mecca and Medina were provided here. Provisions and livestock provided from the east of Sudan

\footnotetext{
${ }^{33}$ Kavas, “Tarihi Süreçte Sahra Altı Afrika”, Sahra Altı Afrika, s. 78.

${ }^{34}$ Cengiz Orhonlu, Osmanlı İmparatorluğunun Güney Siyaseti Habeş Eyaleti, Türk Tarih Kurumu Basımevi, Ankara 1996, s. 175; Tandoğan, Afrika'da Sömürgecilik ve Osmanl Siyaseti, s. 142.

${ }^{35}$ Elem Eyrice Tepeciklioğlu, Türk Dış Politikasında Afrika Temel Dinamikler Firsatlar ve Engeller, Atlas Akademik Basım Yayın Dağıtım Tic. Ltd. Şti, Ankara 2019, s. 9.

${ }^{36}$ İhsan Süreyya Sırma, Osmanlı Devleti’nin Ylkılışında Yemen İsyanları, Selam Yayınevi, Konya 1988, s. 50-52; Durmuş Akalın \& Selim Parlaz, XIX. Yüzyılda Doğu Afrika'da Osmanllar ve İtalyanlar, Kesit Yayınları, İstanbul 2015, s. 14.

${ }^{37}$ Enver Arpa, Afrika Seyahatnamesi, Fecr Yayınları, Ankara 2015, s. 27.
} 
were sent to the holy towns from Suakin Island. The way to reach the Ottoman hinterland along the coast of Somalia was to keep Suakin Island under control. ${ }^{38}$

Suakin Island, which had enjoyed Ottoman rule from the second half of the fifteenth century, was a strategically located part of the Ottoman territory. It had outstanding examples of Ottoman architecture. At the turn of the eighteenth century, there were three mosques in Suakin. Turkish was spoken in Masawa and other settlements. It was a land in which Kuloğulları, who married indigenous women and belonged to the Garb Ocaklar1, lived. ${ }^{39}$ Today, Sudan's internal conflicts have made it difficult for the Republic of Sudan to claim the island, and the island is in an abandoned location. However, it is still a port city that provides shipping for pilgrims. ${ }^{40}$

\section{Masawa Base}

Masawa, which is a base where the Ottoman Empire provided the security of the region against the Portuguese, has been an Ottoman city since 1536. During the Ottoman rule, Masawa was a port where the peoples living in the Horn of Africa opened up to the world. Products produced in inner Ethiopia had spread to the world from Masawa. Masawa was a bustling port where merchants from all over the world mingled.

In every period, it has been a center that powerful states wanted to control. In the early nineteenth century, the port of Masawa became the address where the French attempted to penetrate. The French, who wanted to make their political and military presence clearly dominant in the region, began to penetrate East Africa through Lazarist priests those served on the Red Sea coast for many years.

Through the experts they employed in Egypt, the French tried to gain superiority in the field. With its strong influence over Egypt, it attempted to dominate the Red Sea and East Africa coasts. In this framework, the French opened their own consulates in 1841 and the British in 1848 in Abyssinia. Working on behalf of France as an engineer, Webé worked hard to open the French consulate in Masawa. With the support of Catholic missionaries, he succeeded to open the French consulate in 1841. After the consulate building was opened, Webé tried to increase French influence in Masawa, coordinate Catholic missionaries, and fight against Reis Ali, who was influential in the Abyssinian lands. As Webé continued their consular initiatives in Masawa, an English Walter Ploeden, began initiatives as British consul in Msawa in 1848. Like Webé, Ploeden tried to establish a relationship with Reis Ali in Abyssinia. With the cities of Suakin and Masawa being connected first to the Hejaz and then back to Egypt, the French and British officials made an effort to take their own position. European powers accelerated diplomatic relations

\footnotetext{
${ }^{38}$ Enver Arpa, Afrika Satrancında Sudan (Hatıralar/İzlenimler), 2. Baskı, Meneviş Yayınları, Ankara 2013, s. 32.

${ }^{39}$ Haluk Dursun, Nil'den Tuna'ya Osmanl, Timaş Yayınları, 6. Baskı, İstanbul 2016, s. 273.

${ }^{40}$ Arpa, Afrika Satrancinda Sudan, s. 32.
} 
with the region's second subordination to Egyptian rule, and tried to use their influence over the Egyptian Khedive to their advantage. ${ }^{41}$

Walter Chichele Plowden was the first British consul in Masawa. Plowden was famous for his trips and research. He worked hard for Masawa to become a British colony. When he was murdered in 1860, Captain Charles Duncan Cameron was appointed to his place. ${ }^{42}$

\section{Zeila Sanjak}

The most important trade center where Arab, Somalian and Afar merchants settled was the city of Zeila. Zeila merchants shuttled between Jeddah, Yemen, Basra Gulf and India. The fact that it is both a commercial town and a functioning port has made the town of Zeila a center of attraction throughout history. Zeila, which came under Ottoman rule in 1520 , became a sanjak that was ruled under the Ottoman provinces of Ethiopia and Yemen for a long time. In the second half of the nineteenth century, as a result of the efforts of Khedive Ismail Pasha, Egypt was attached to Sudan. The fairs set up in Zeila every year increased the attraction for Zeila. Trade goods from the east and west increased the economic power of the city. Italians established a port colony in Assab in 1881 to eliminate the Zeila port and its commerce. With the will given by Abdülhamid II on 19 August 1879, Zeila became a part of the Ottoman Empire until this date. When Egypt was occupied by the British in the second half of the nineteenth century, Zeila ceased to be a part of Egyptian Sudan and was directly connected to Istanbul. The presence of the Ottoman State here ended in $1916{ }^{43}$

The French wanted to take down the Ottoman flag in Zeila in 1885, and the Italians looked out for ways to dominate Zeila. However, the Ottoman efforts to fly the Ottoman flag in Zeila continued until the end of the nineteenth century by preserving its own military garrison, albeit small, in Zeila so as to to ensure that Zeila paid taxes to Masawa. ${ }^{44}$

\section{Leaving Suakin and Masawa to the Egyptian Administration}

In the nineteenth century, Britain, which followed an active Red Sea policy, increased its voyages to the port of Masawa, explored ways to dominate this strategically important port of the Ottoman Empire, and the position of British merchants and travelers began to be replaced by armed military forces in time. Deployed in Yemen and San'a on the opposite side, British forces gradually began to penetrate the local population in Suakin and Masawa. In the face of these moves of the British, the Ottomans started a mobility in Suakin and Masawa. Despite the weakening of the direct domination of the Ottoman

\footnotetext{
${ }^{41}$ Donald Crummey, "Initiatives and Objectives in Ethio-European Relations 1827-1862", The Journal of African History, c. 15, No. 3, Cambridge University Press, 1974, s. 434-438; Akalın \& Parlaz, Doğu Afrika'da Osmanllar ve Italyanlar, s. 24-25.

${ }^{42}$ Akalın \& Parlaz, Doğu Afrika'da Osmanllar ve Italyanlar, s. 26.

${ }^{43}$ Ahmet Kavas, “Doğu Afrika Sahili'nde Osmanlı Hakimiyeti: Kuzey Somali'de Zeila İskelesi'nin Konumu 12651334/1849-1916", İslam Araştırmaları Dergisi, İstanbul 2001, Sayı: 5, s. 109-134; Tandoğan, Afrika'da Sömürgecilik ve Osmanl Siyaseti, s. 145.

${ }^{44}$ Akalın \& Parlaz, Doğu Afrika'da Osmanllar ve İtalyanlar, s. 209.
} 
central government in the region in view of the Turkish-Egyptian administration that started to be established in 1821, Mehmed Ali Pasha of Kavala regarded Masawa as the key point for his rule. At the request of Mehmed Ali Pasha, the ports of Suakin and Masawa were left to the Egyptian administration by Sultan Abdulmejid in 1846. Suakin and Masawa ports remained in Egyptian hands between 1846-1849. British forces were disturbed by this allocation made to Mehmed Ali Pasha. Then the British started to increase their trade relations with the Kingdom of Abyssinia and signed a trade agreement thereof.

\section{Suakin ve Masawa to the Jeddah Governorship}

Following the death of Mehmed Ali Pasha and the foreign developments experienced, Egyptian administrators stated that they could not manage these places and thought of withdrawing from Masawa and its surroundings. Upon this, the Ottoman State decided to attach Suakin and Masawa to the Jeddah Governorship, to reconstruct its law in East Africa and take measures to prevent financial losses so as not to damage their territorial integrity. With a letter sent on April 2, 1849, it was decided that the ports of Suakin and Masawa were again administrated by the Jeddah Governorate. It was decided to reorganize an imperial army instead of the native Egyptian forces, which provided security in Egyptian rule. The governor of Jeddah was asked to ensure proper customs duties and ensure military security on time. ${ }^{45}$

The linking of Suakin and Masawa to the Ottoman central administration disturbed the British and French forces. The British and French consuls were annoyed by the actions of the Masawa district governors. They often sent ambassadors to Istanbul to declare their discomfort.

Despite the hindering efforts of the foreign consulates, the Ottoman State always supported the district governors in Masawa and asked them to take a decisive stance in establishing the Ottoman authority. For example, on March 18 1856, Masawa district governor Mehmed Emin stated in his letters to Istanbul that settlements such as Senhit and Mensa between the district governorship and Abyssinia were connected to Masawa, and that he tried to include them in the Masawa administration by establishing close contacts with the tribes living in Abyssinia. ${ }^{46}$ The French consul Webé, bought a land in the port of Masawa from a person named Naib Yahya. He built a church on the land he expropriated. These developments were reported to the Ottoman governor of Jeddah. In the correspondence with the Masawa administrators for investigation, the governor of Jeddah asked that if Naib Yahya received money from the French Consul in return for the land, and that if he should be contacted immediately, the money he received was to be returned to him; the land would be saved without being uprooted, and the expropriation of the land by foreigners in Masawa would not be tolerated. Masawa district governor,

${ }^{45}$ Akalın \& Parlaz, Doğu Afrika'da Osmanlılar ve İtalyanlar, s. 39.

${ }^{46}$ Akalın \& Parlaz, Doğu Afrika'da Osmanlılar ve İtalyanlar, s. 86-87. 
Mehmed Pasha, in his correspondence with the Governor of Jeddah, replied that whatever was necessary was done and that they prevented foreigners from purchasing land. ${ }^{47}$

The Ottoman State gave a comprehensive instruction to Mehmed Pasha for his new post. In the instruction given, it was requested that the Ottoman administration ought to be reestablished in the region. Mehmed Pasha was allowed to move freely on the condition of following the regulations of the central state. He was asked to prevent Europeans from settling in the region. Mehmed Pasha was also asked to take the necessary measures to prevent foreign powers from penetrating the region in the context of political, diplomatic, commercial and cultural relations, and to prevent the purchase of land within the region. Complaints about Suakin and Masawa's becoming a meeting point for foreigners were transmitted to him. He was also informed about the rise of intrigues in the region after the settlement of foreign consulates. While the Ottoman State was trying to ensure domination and tranquility in the region with such initiatives, attacks, appointments and instructions, the Yemen problem bursted in 1849. It delayed the realization of Ottomans' goals, maintaining the order it aimed, making fast and proper decisions, and the order it wanted to rebuild in East Africa. The plan to take control of Yemen was brought forward and the initiatives in East Africa were taken back. ${ }^{48}$

Mehmed Pasha, who was one of the Ottoman officers in Tripoli at that time, was given the administration of Masawa, which was taken from the Egyptian administration and reacquired by the Ottoman Empire and was ruled from Jeddah. Due to the sensitive position of the region, especially Mehmed Pasha was chosen as a governor general. As the consuls in Masawa often conveyed the discomfort they felt from Mehmed Pasha to the Ottoman Empire, a crisis emerged by making a federal case out of minor problems, and the military activity in Yemen left the Ottoman administration in Jeddah in a difficult situation. The fact that Jeddah was ruling a vast territory, the difficulties in meeting the demands of points such as Masawa in terms of material and military has brought Masawa's administration over Yemen from Hejaz. ${ }^{49}$

Foreign consulates made complaints to the Ottoman Government with serious allegations that the district governorship of Masawa was engaged in captive and slave trade. The Ottoman Government appointed the Governor of Jeddah to investigate these allegations and to conduct an on-site investigation. Grand Vizier Kamil Pasha, who cared much about Masawa and Suakin in every respect, did not want to harm his strategic position and thought that European states should not intervene more, stated in a letter he sent to the Governor of Jeddah on $2^{\text {nd }}$ December 1859, that the District Governor of Masawa was dismissed. Pertev Efendi, who is believed in his merit and is expected to maintain

\footnotetext{
${ }^{47}$ Akalın \& Parlaz, Doğu Afrika'da Osmanlilar ve İtalyanlar, s. 42.

${ }^{48}$ Akalın \& Parlaz, Doğu Afrika'da Osmanllar ve İtalyanlar, s. 297.

${ }^{49}$ Akalın \& Parlaz, Doğu Afrika'da Osmanllar ve Italyanlar, s. 77.
} 
diplomatic relations with foreigners, has been deemed appropriate to the District Governorship of Masawa. ${ }^{50}$

\section{Relinking of Suakin and Masawa to Egypt}

In the first half of the nineteenth century, the city of Masawa witnessed a mutual competition for influence between the Ottomans and the French and the British whereas in the second half of the century, the Italians began to seek rights over Masawa. At the ports of Masawa and Suakin, the British, Italian and French started to set up accounts after account. Upon these negative developments, Khedive İsmail Pasha stepped in again for both ports in 1865. ${ }^{51}$ The demands of the Egyptian Khedive Ismail Pasha on Suakin and Masawa were assessed to be right, and in 1865, the port of Suakin and Masawa was left under the control of Ismail Pasha. ${ }^{52}$

With the opening of the Suez Canal on $17^{\text {th }}$ November 1869, the interest of both the Western states and the Ottomans in the East African coast increased, and the Red Sea witnessed a race for domination among international powers. The Ottoman Empire, which increased its effectiveness in the Red Sea, closely followed the European states' interest in the region. The reports that France and Italy acquired lands in different parts of Bāb al-Mandeb and the Red Sea on $7^{\text {th }}$ July 1870 , seriously worried the Ottoman authorities. Upon the new developments in the Red Sea following the opening of the Suez Canal, the Ottoman State sent troops to the region. The French, uncomfortable with the British positions in the Suez Canal, had to deal with Masawa. Realizing that it is not easy to settle in Masawa and its surroundings, France now had its eyes on the Arabian Peninsula beaches. Mustafa Asım Bey stated in his report addressed to Ottoman Premiership from Sana on $23^{\text {rd }}$ September 1875 that the land called Sheikh Saild on the coast of the Arabian Peninsula, close to Bāb al-Mandeb, was attempted to be sold to two French citizens by a tribal sheikh. In the Zeila Directorate, the news of newly discovered coal mine was announced at the same time. The Commander of the Red Sea, Ali Efendi, who was asked to act for the determination of the situation, prepared five pieces of maps regarding the ports of Bāb al-Mandeb, Zeila, Seikh Saìd, Moha and Tacura and the conditions of those places. Moreover, a port and fortification was requested in Sheikh Said..$^{53}$ Within the scope of the measures taken in the region in military terms, the Ottoman State kept the port of Bāb al-Mandeb with its ships and assigned two troops in the Bāb al-Mandebbastion. A battalion of Ottoman soldiers and two continents of artillery tried to defend the coast of Masawa and Bāb al-Mandebagainst possible attacks by Italian and British warships going back and forth in $1885 .{ }^{54}$

\footnotetext{
${ }^{50}$ Akalın \& Parlaz, Doğu Afrika'da Osmanlılar ve İtalyanlar, s. 96.

${ }^{51}$ Akalın \& Parlaz, Doğu Afrika'da Osmanlılar ve İtalyanlar, s. 113.

${ }^{52}$ Orhonlu, Habeş Eyaleti, s. 148; Akalın \& Parlaz, Doğu Afrika'da Osmanlılar ve İtalyanlar, s. 114.

${ }^{53}$ Akalın \& Parlaz, Doğu Afrika'da Osmanlilar ve İtalyanlar, s. 158-159.

${ }^{54}$ Akalın \& Parlaz, Doğu Afrika'da Osmanlılar ve İtalyanlar, s. 202.
} 
Upon the opening of the Suez Canal, Suakin turned into a dynamic port city and its importance increased. In the port of Suakin, a commercial activity based on the exchange method would take place. Mostly, grains and textile products were traded. The crops of the fertile Swahili lands would also be abundant. ${ }^{9}$ Wheat and other food items of the Abyssinian State would come from lands under the Func Sultanate. ${ }^{55}$ When Khedive Ismail Pasha dominated the ports of Suakin and Masawa, he continued his military activities in the area from the Red Sea, the Gulf of Aden and the coast of Somalia to Cape Guardafui, and used Suakin as a base. ${ }^{56}$

Supporting Britain on the case of Egypt, Italy was trying to become an effective power in the Mediterranean. Unable to get what it wanted in the Mediterranean; Italy considered the Red Sea beaches as a new area of opportunities with the opening of the Suez Canal in 1869. Italy, which started by establishing a coal station in the Assab Gulf in 1869, tried to achieve its goals by seizing Masawa in $1885 .{ }^{57}$ The competition of Ottoman, British and Italian forces in Masawa evolved into the process that led to British rule with the British military expedition in $1893 .^{58}$

\section{Partition of East Africa by European States}

With the Berlin Africa Conference held in 1884-85, being one of the European states that shared the African geography among themselves, Britain occupied the majority of East Africa. To this effect, England established the British East Africa Company in order to control the region, maintain its expansionist policy and increase its influence. ${ }^{59}$

Another European country that acquired a large colonial area in East Africa was Germany. A German sailor named Carl Peters established a society called "Gesellschaft für Deutsche Colonization" and as a result of the agreements signed with the indigenous tribes of East Africa, he seized $140.000 \mathrm{~km} 2$ of land on behalf of Germany. After Carl Peters entered the Great Lakes Basin, the British were worried, and thus Britain took action with the concern that Germans would dominate the land and Nile resources held by the Mahdi supporters. As a result of negotiations with Germany, the Anglo-German agreement was signed on June $15,1890 .{ }^{60}$ France, which has a dominant position in West and Central Africa, also tried to gain a dominant position in East Africa. Over time, Britain, Germany and France became rival states in East Africa. Realizing the course of developments early, Britain

\footnotetext{
${ }^{55}$ Tandoğan, Afrika'da Sömürgecilik ve Osmanl Siyaseti, s. 143.

${ }^{56}$ Orhonlu, Habeş Eyaleti, s. 148; Akalın \& Parlaz, Doğu Afrika'da Osmanlılar ve İtalyanlar, s. 114.

${ }^{57}$ Akalın \& Parlaz, Doğu Afrika'da Osmanlılar ve İtalyanlar, s. 174.

${ }^{58}$ Tandoğan, Afrika'da Sömürgecilik ve Osmanl Siyaseti, s. 144.

${ }^{59}$ Cihan Daban, "Bağımsızlıktan Günümüze Uganda Cumhuriyeti ve D1ş İlişkileri”, Dünya Siyasetinde Afrika 5, ed. İsmail Ermağan, Nobel Yayınları, Ankara 2018, s. 124-125.

${ }^{60}$ Abdurrahman Çayc1, Büyük Sahra'da Türk-Fransız Rekabeti (1858-1911), Türk Tarih Kurumu Basımevi, Ankara 1995, s. 76.
} 
tried to reinforce its sovereignty in the region and block Germany and France in a short time. ${ }^{61}$

Although the French, British and Italian ambitions started to come true one by one, the Ottoman Empire, which organized Suakin and Masawa as bases, regarded these places as dependent even in 1893. The fact that the Ottoman State regarded these places as bases affiliated to it resulted in declaring that the occupation carried out by Italy was illegitimate. The effect of this decision did not give the desired result, as it could not be supported at the desired level in time and in financial and military terms. ${ }^{62}$

The British completed the occupation of Sudan in 1898 and built the Port Sudan in Suakin for political and cultural concerns. They tried to isolate Suakin island from its historical identity with the construction of the new modern harbor. Especially after the First World War, the Suakin port completely lost its importance and was turned into a ruin.

The old state of the city is extremely magnificent in the pictures and models of Suakin, which had been under Ottoman rule for centuries. There are many historical buildings on the island bearing the traces of Ottoman architecture. Customs buildings, administrative buildings, officers' houses and most of the public houses were built during the rule of the Ottoman pashas.

However, this magnificent structure had unfortunately turned into a complete ruin today as a result of negligence. There exists hardly any surviving building in the city. Timeconsuming plundering and natural events completely destroyed the buildings. The Sudanese government could not protect it properly due to its internal problems. ${ }^{63}$

The ruined historical buildings have been abandoned by the people in time. The port of Suakin is still used today for the shipment of Sudanese pilgrims and small-scale sea shipping. ${ }^{64}$ Once being continued its existence as an Ottoman base between 1517-1865, the island of Sevan was allocated to Turkey and it has been asked to be rebuilt. ${ }^{65}$

\section{Conclusion}

East Africa is an important part of Islamic civilization. It formed the ground for the formation of an independent civilization under the name of Kiswahili civilization. As a result of the migrations that took place during both the times of Umayyads and the Abbasids, Muslims had spread to the region since the first periods of Islamic history. Muslims who came to the region tried to be active in the region with political, commercial and religious motives. The region, which met Islam in the early periods, also hosted many other Muslim dynasties.

\footnotetext{
${ }^{61}$ Cihan Daban, “Bağımsılılıktan Günümüze Uganda Cumhuriyeti ve Dış İlişkileri”, Dünya Siyasetinde Afrika 5, ed. İsmail Ermağan, Nobel Yayınları, Ankara 2018, s. 124-125.

${ }^{62}$ Orhonlu, Habeş Eyaleti, s. 157; Akalın \& Parlaz, Doğu Afrika'da Osmanllar ve İtalyanlar, s. 285.

${ }^{63}$ Enver Arpa, Afrika Satrancında Sudan (Hatıralar/İzlenimler), 2. Baskı, Meneviş Yayınları, Ankara 2013, s. 31.

${ }^{64}$ Enver Arpa, Afrika Seyahatnamesi, Fecr Yayınları, Ankara 2015, s. 27.

${ }^{65}$ Tepeciklioğlu, Türk Dış Politikasında Afrika, s. 9.
} 
Early sixteenth century marked a milestone in the journey of existence of East-African Muslims. Spanish and Portuguese powers, which took a course of dominance as a result of the fall of Andalusia, opened to the Mediterranean and Indian Ocean. The Ottoman navy, struggling for independence against the Spanish navies in the Mediterranean, also fought for independence against the Portuguese occupation navy in the Red Sea and Indian Ocean.

The Portuguese plundered the port cities on the East African coast, seized the treasures of the coastal civilization that emerged in about eight centuries, and the Muslim lands that were built throughout history were plundered and turned into ruins. In the years when the Ottoman Empire conquered Egypt, the Portuguese also defeated the Mamluk fleet and the Portuguese navy came to Jeddah. Alarmed with the miserable situation, the Ottoman administration took action by adding the Mamluk navy to its own naval forces and sailed to the Red Sea. This landing of the Ottoman navy on the East African coasts enabled the Muslim sultanates in both the Red Sea and the Indian Ocean to be under the protection of the Ottoman Empire against the Portuguese. The presence of Portugal in the Red Sea, which coincided with the year when Yavuz Sultan Selim conquered Egypt, disturbed the Ottomans. They were defeated in the Indian Ocean in a manner not to return to the Red Sea for this purpose, with the naval contingent immediately sent to them.

Ottoman sailors, who came to the aid of East African Muslims in the second half of the $16^{\text {th }}$ century, fought with the Portuguese here for years. However, the land troops sent to the northern and Red Sea coasts of Africa could not be sent to the East African coast. More naval troops were mobilized to the aid of the East African peoples. Another helping hand that came to the aid of East African Muslims against the Portuguese was extended by the Sultanate of Oman. Thanks to the help of the Ottoman Empire and the Sultanate of Oman, the Islamic civilization was revived in this part of the continent and had the opportunity to spread to the interior of Kenya, Tanzania, Rwanda, Congo, Malawi and Mozambique.

The Red Sea points of strategic importance such as Harar, Suakin, Masawa, Zeila, Berbera and Harar, which were revived by the Swahili civilization, the Harar Sultanate, the Ottoman Empire and the Oman Dynasty, were the centers where the connection between the Arabian Peninsula and Africa was strengthened. These were both the keys to the Mediterranean trade and the gateways to the interior of Africa. The Ottoman Empire, which prevented Portuguese forces from entering the Bāb al-Mandeb Strait and obstructed their presence in the Red Sea, ensured that the Red Sea remained under the control of the Abyssinian, Hijaz and Yemen provinces from the sixteenth century to the nineteenth century. The empire also prevented the sacred lands such as Mecca and Medina from the damage of a possible foreign invasion for centuries. The Ottoman hinterland in Suakin, Masawa, Zeila and Harar served as a base for the opening of the Ottoman Empire to the Indian Ocean, as well as to maintain peace in the Red Sea. The Ottoman Empire tried to keep these port cities in the Red Sea until the end of the 
nineteenth century and continued to deal with the problems of East African Muslims until the end, even if its military presence in the region had decreased over time. In the East African geography, where the Ottoman Empire extended a helping hand in the sixteenth century, the Portuguese colony was eliminated, the region was allowed to live in peace between the sixteenth and nineteenth centuries, leading to a delay in colonialism in the region. 


\section{References}

Akbay, Oktay Salih, "Doğu Afrika Ekonomileri", Dünya Siyasetinde Afrika 2, ed. İsmail Ermağan, Nobel Akademik Yayıncılık, Ankara 2015, s. 323-343.

Arpa, Enver, Afrika Satrancında Sudan (Hatıralar/İzlenimler), 2. Baskı, Meneviş Yayınları, Ankara 2013

Arpa, Enver, Afrika Seyahatnamesi, Fecr Yayınları, Ankara 2015.

Aydın, Hakan, "Eleştirel Jeopolitik Perspektifi İle Kızıldeniz", Dünya Siyasetinde Afrika 3, ed. İsmail Ermağan, Nobel Yayınları, Ankara 2016, s. 257-273.

Bayur, Y. Hikmet, Hindistan Tarihi, Türk Tarih Kurumu Basımevi, Ankara 1987.

Crummey, Donald, "Initiatives and Objectives in Ethio-European Relations 1827-1862", The Journal of African History, c. 15, No. 3, Cambridge University Press, 1974, s. 433-444.

Çaycl, Abdurrahman, Büyük Sahra'da Türk-Franslz Rekabeti (1858-1911), Türk Tarih Kurumu Basımevi, Ankara 1995.

Daban, Cihan, "Etiyopya-Somali İlişkileri: Ogaden Savaşı", Dünya Tarihinde Afrika 4, ed. İsmail Ermağan, Nobel Akademik Yayıncılık, Ankara 2017, s. 248-270.

Daban, Cihan, "Bağımsızlıktan Günümüze Uganda Cumhuriyeti ve Dış İlişkileri”, Dünya Siyasetinde Afrika 5, ed. İsmail Ermağan, Nobel Yayınları, Ankara 2018, s. 121-139.

Dursun, Bahtiyar, "Doğu Afrika'da Yenilebilir Enerji Kaynakları: Potansiyel ve Yatırımlar", Dünya Siyasetinde Afrika 3, ed. İsmail Ermağan, Nobel Yayınları, Ankara 2016, s. 373406.

Dursun, Haluk, Nil'den Tuna’ya Osmanl, Timaş Yayınları, 6. Baskı, İstanbul 2016.

Gezahegn, Abebaw Fentahun, Tarihte Jimma Şehri, Yayınlanmamış Yüksek Lisans Tezi, Gazi Üniversitesi Sosyal Bilimler Enstitüsü, Ankara 2016

Hazar, Numan, Küreselleşme Sürecinde Afrika ve Türkiye-Afrika İlişkileri, Usak Yayınları, 2. Bask1, Ankara 2011.

İbn Battûta, Ebû Abdullah Muhammed Tancî, İbn Battûta Seyahatnâmesi, çev. A. Sait Aykut, Yapı Kredi Yayınları 2. Baskı, İstanbul 2004.

Kavas, Ahmet, Geçmişten Günümüze Afrika, Kitabevi, İstanbul 2005.

Kavas, Ahmet, Geçmişten Günümüze Afrika, Kitabevi, 2. Baskı, İstanbul 2017.

Kavas, Ahmet, Osmanll-Afrika İlşskileri, TASAM Yayınları, İstanbul 2006. 
Kavas, Ahmet, "Tarihi Süreçte Sahra Altı Afrika: Osmanl1-Afrika İlişkileri ve Sömürgecilik", Sahra Altı Afrika, trc. Begüm Eda Şahin, ed. Ahmet Kavas \& Ufuk Tepebaş, Tasam Yayınları, İstanbul 2007, s. 75-84.

Kavas, Ahmet, "Doğu Afrika Sahili'nde Osmanlı Hakimiyeti: Kuzey Somali'de Zeila İskelesi'nin Konumu 1265-1334/1849-1916", İslam Araștrrmaları Dergisi, İstanbul 2001, Say1: 5, s. 109-134.

Koçak, Mehmet, Mehdi Hareketinden İslâm Devrimine Sudan, Esra Yayınları, Konya 1999.

Özbaran, Salih, Umman'da Kapışan İmparatorluklar Osmanlı ve Portekiz, Tarihçi Kitabevi, İstanbul 2013.

Özey, Ramazan, "Doğu Afrika Panoraması: Siyaset-Toplum-Ekonomi”, Dünya Siyasetinde Afrika 3, ed. İsmail Ermağan, Nobel Yayınları, Ankara 2016, s. 1-52.

Öztuna, Yllmaz, “Orta ve Doğu Afrika'da Türkler”, Hayat Tarih Mecmuası, No. 7, Ağustos 1973, s. 8-22.

Sırma, İhsan Süreyya, Osmanlı Devleti’nin Yıkllşıında Yemen İsyanları, Selam Yayınevi, Konya 1988.

Tandoğan, Muhammed, Afrika'da Sömürgecilik ve Osmanl Siyaseti (1800-1922), Türk Tarih Kurumu Yayınları, Ankara 2013.

Tepeciklioğlu, Elem Eyrice, Türk Dış Politikasında Afrika Temel Dinamikler Firsatlar ve Engeller, Atlas Akademik Basım Yayın Dağıtım Tic. Ltd. Şti, Ankara 2019.

Utku, Nihal Şahin, Kızıldeniz'de Denizcilik, Ticaret ve Yerleşim (VII-XI. Yüzyıllar), Doktora Tezi, Marmara Üniversitesi Sosyal Bilimler Enstitüsü, İstanbul 2005

Uzunçarşıll, İ. Hakkı, Osmanlı Tarihi, Türk Tarih Kurumu Basımevi, Ankara 1995. 